CASE REPORT

\title{
Initial Experience with O-Arm Navigated Spinal Surgery - Report on Two Cases
}

\author{
Ivo I. Kehayov ${ }^{1,2}$, Christo B. Zhelyazkov ${ }^{1,2}$, Borislav M. Kalnev ${ }^{1,2}$, Atanas N. Davarski ${ }^{1,2}$, \\ Borislav D. Kitov ${ }^{1,2}$, Stefan D. Raykov²
}

1 Department of Neurosurgery, Faculty of Medicine, Medical University of Plovdiv, Plovdiv, Bulgaria

2 Clinic of Neurosurgery, St. George University Hospital, Plovdiv, Bulgaria

\section{Correspondence:}

Ivo I. Kehayov, Department of Neurosurgery, Faculty of Medicine, Medical University of Plovdiv, 15A Vassil Aprilov Blvd, Plovdiv 4000, Bulgaria

E-mail:dr.kehayov@gmail.com; dr.kehayov@yahoo.com

Tel: +359 899105352

Received: 24 April 2016

Accepted: 05 July 2016

Published Online: 05 Oct 2016

Published: 23 Dec 2016

Key words: O-arm, pedicle screw fixation, spinal surgery

Citation: Kehayov II, Zhelyazkov CB, Kalnev BM, Davarski AN, Kitov $B D$, Raykov SD. Initial experience with O-Arm navigated spinal surgery - report on two cases.

Folia Medica 2016;58(4):293-298 doi: 10.1515/folmed-2016-0033
Image-guided spinal surgery is becoming increasingly popular because it allows surgeons to achieve minimal invasiveness and maximum precision in the performed procedures.

We present our initial experience with two cases operated on using O-arm-based spinal navigation at the Clinic of Neurosurgery in St George University Hospital, Plovdiv, Bulgaria. In the first case, we performed removal of extradural spinal tumor of the sixth thoracic vertebra and O-arm-navigated pedicle screw fixation. In the second case, we performed O-arm-navigated corpectomy of the fifth cervical vertebra and anterior spinal reconstruction and fusion with titanium expandable mesh and cervical plate in connection with degenerative narrowing of the cervical spinal canal that lead to clinically manifested myelopathy.

The initial experience allows us to conclude that O-arm-based image-guided spinal surgery can lead to considerably higher precision of spinal instrumented procedures. At the same time, it reduces the irradiation dose of the patient and surgical team.

\section{INTRODUCTION}

Development and introduction of novel intraoperative navigational systems have boosted a substantial progress in the modern spinal surgery. These techniques for image-guided surgery provide real-time multiplanar images of spine anatomy. ${ }^{1}$ Concerns surrounding the adoption of these technologies include cost and increased operating times, but improvements in design and protocol may improve the integration of these imaging modalities in the operating room. ${ }^{2}$

The present study reports on the first two cases in Bulgaria concerning patients with spinal diseases. These patients were operated on using a system for intraoperative image-guided spinal surgery, the O-arm ${ }^{\circledR}$ Surgical Imaging with StealthStation S7 ${ }^{\circledR}$ Navigation (Medtronic Sofamor Danek, Inc., Memphis, TN, USA).

\section{CASE 1}

A forty-one-year-old man presented with a 6-month history of increasing severe back pain that irradiated to the right half of the mid-thorax. Neurological examination revealed right-sided $T_{6}$ intercostal neuralgia without any conductive motor or sensory loss and preserved bowel and bladder control. He was graded 0 on the Nurick Scale. The pre-operative computed tomography (CT) scanning demonstrated extradural homogenously enhancing lesion that had destroyed part of the $T_{6}$ vertebral body, the right pedicle and right half of the vertebral lamina. A subsequent magnetic resonance imaging (MRI) of the thoracic spine was performed that confirmed the localization of the lesion causing ventral and right lateral compression of the medulla in the affected segment (Fig. 1 A-C). 


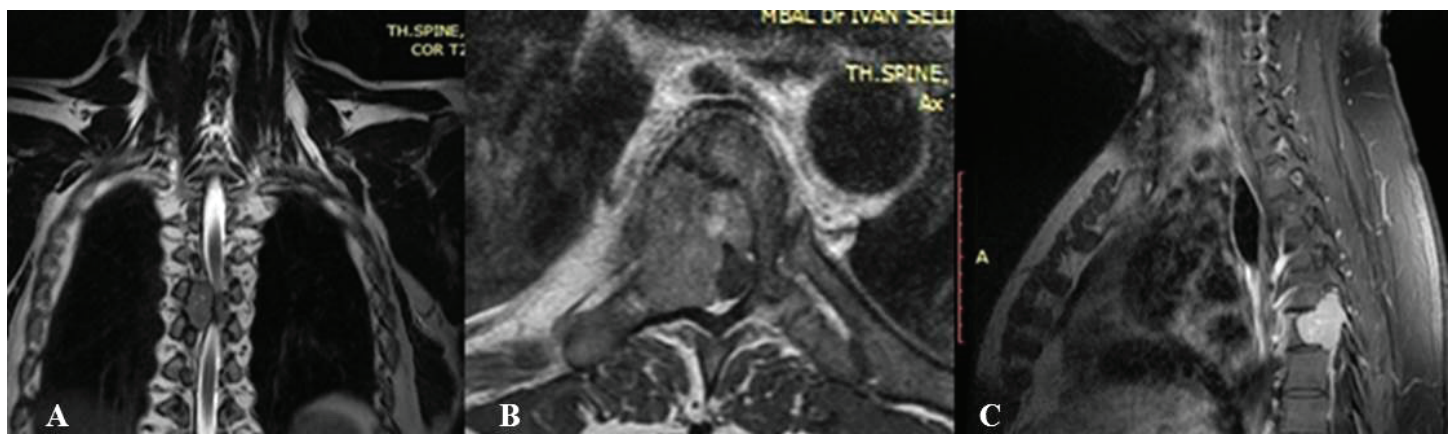

Figure 1. Preoperative MRI of the thoracic spine: (A) Coronal $\mathrm{T}_{2}$ image; (B) Axial $\mathrm{T}_{1}$ image with contrast enhancement; (C) Sagittal $\mathrm{T}_{1}$ image with contrast enhancement.

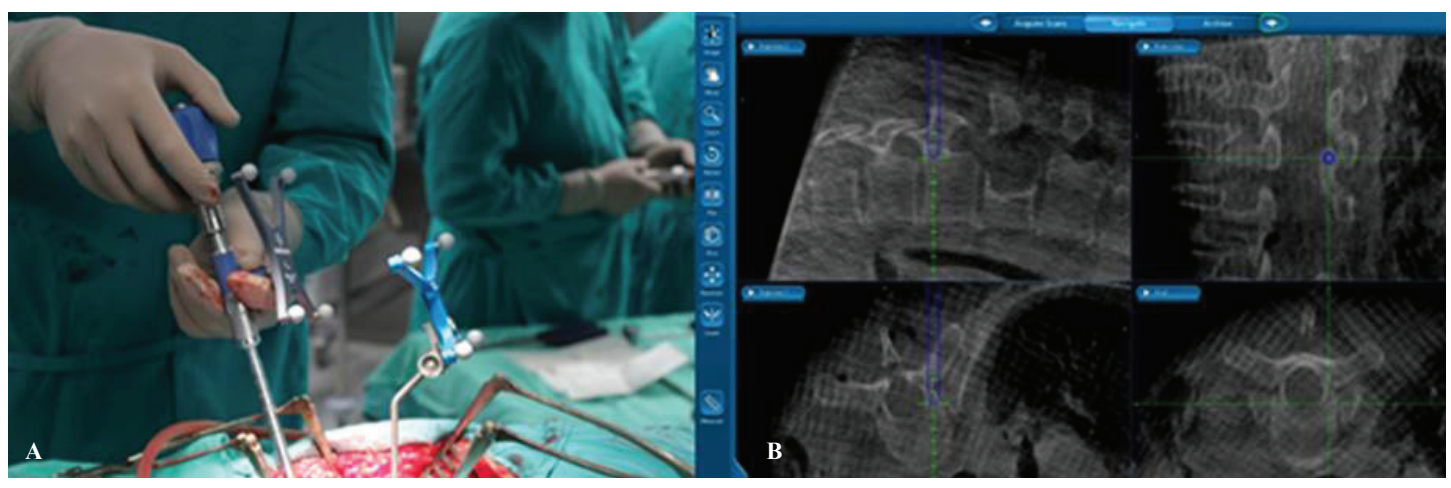

Figure 2. (A) - (B). Image-guided pedicle screw fixation.

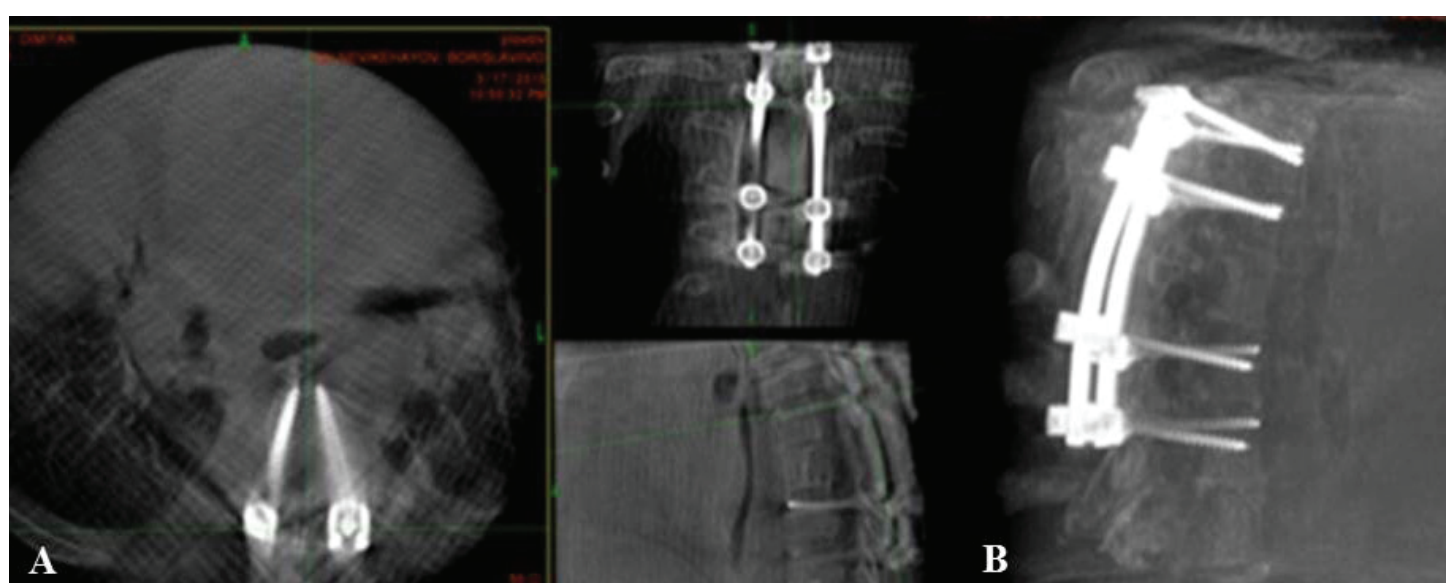

Figure 3. (A) - (B). Postprocedural intraoperative 3D O-arm scanning.

\section{SURGERY AND FOLLOW-UP}

The patient was positioned prone on the operating table. A standard posterior midline approach was performed in the affected thoracic segment, the paravertebral muscles were stripped off the posterior elements from $T_{4}$ to $T_{8}$ vertebrae with presentation of the entry points for pedicle screw placement. The navigational frame was attached to the spinous process of $\mathrm{T}_{6}$ vertebra. Then, intraoperative O-arm scanning of $\mathrm{T}_{4}-\mathrm{T}_{8}$ segment was conducted followed by automatic data transfer of images to the StealthStation $S 7^{\circledR}$ Navigation System. Subsequently, the navigated instruments for pedicle screw fixation were verified. Eight pedicle screws were implanted in $\mathrm{T}_{4}$, $\mathrm{T}_{5}, \mathrm{~T}_{7}$ and $\mathrm{T}_{8}$ vertebrae, respectively, by means of the intraoperative 3D image-guided navigational control (Figs 2A, 2B). A final intraoperative O-arm scanning was performed to verify proper screw placement and stabilization assembly (Figs 3A, 3B). Resection of the extradural tumor was carried out via right-sided $\mathrm{T}_{6}$ hemilaminectomy and arthropediculotomy

Histological and immunohistochemical analyses identified undifferentiated pleomorphic sarcoma, 


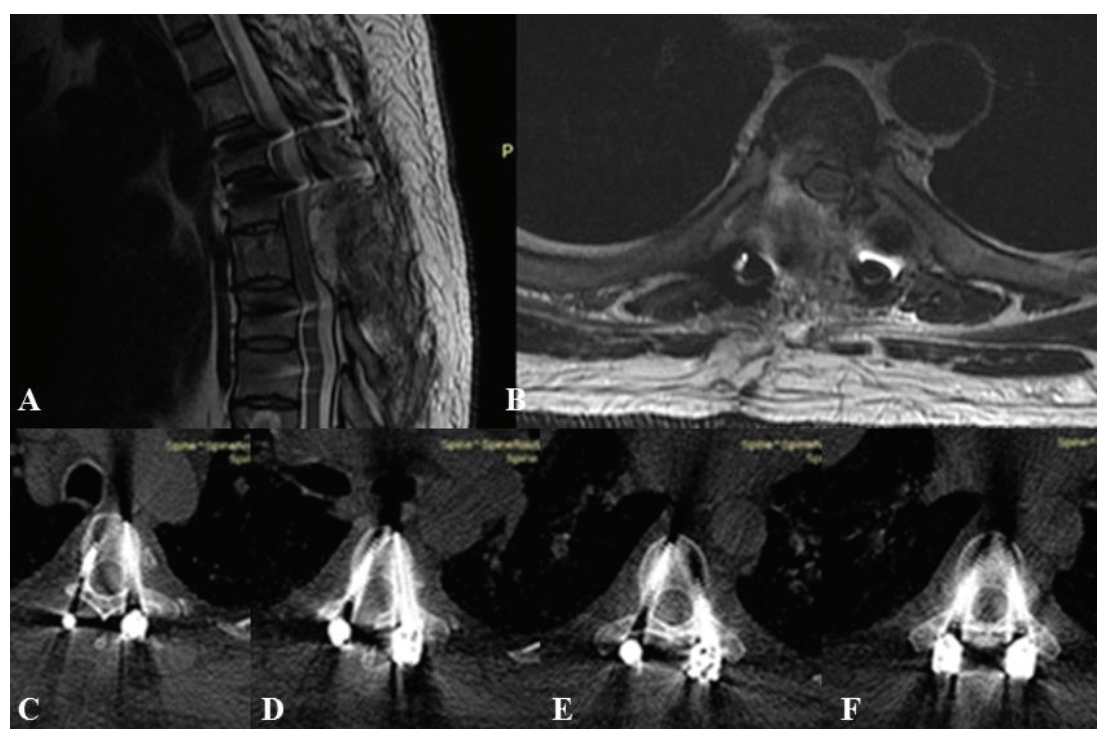

Figure 4. Postoperative MRI (A-B) and CT (C-F) showing the extent of spinal cord decompression and proper pedicle screw placement in $\mathrm{T}_{4}, \mathrm{~T}_{5}$, Т7 и Т8 vertebrae.

according to the WHO classification. Postoperative thoracic CT and MRI performed 10 days postoperatively confirmed the scope of resection and the proper implantation of the pedicle screw fixation system (Fig. 4 A-E). The postoperative period was uneventful. The clinical examination at 6 months postoperatively found complete pain resolution, the patient remained neurologically intact - Grade 0 on the Nurick Scale.

\section{CASE 2}

A seventy-seven-year-old male had a 5-month history of progressive symptoms of cervical spondylotic myelopathy. The neurological deficit included spastic quadriparesis with prominent bilateral grasp weakness, hypereflexia, pathological reflexes in the lower and upper extremities and conductive hypesthesia distal from the clavicles. The patient was scored 8/17 on the Japanese Orthopaedic Association
(JOA) Scale. Preoperative MRI of the cervical spine demonstrated severe degenerative spondylogenic and discogenic stenosis of the spinal canal that was most demonstrative in the $\mathrm{C}_{4}-\mathrm{C}_{5}-\mathrm{C}_{6}$ segment. Additionally, the $T_{2}$ images showed hyperintensity in the affected segment of the spinal cord (Fig. 5 A-C).

\section{SURGERY AND FOLLOW-UP}

The patient was positioned supine on the operating table with the head fixed in neutral position in a skull clamp. The cranial navigational frame was then attached to the skull clamp. Afterwards, initial 3D O-arm scanning of the cervical spine was conducted. The data was automatically transferred to the StealthStation $S 7^{\circledR}$ Navigational System. The cranial navigational probe was verified. The neck was slightly extended. Anterior image-guided cervical corpectomy was performed followed by $\mathrm{C}_{4}-\mathrm{C}_{6}$ fusion with titanium expandable mesh and plate.

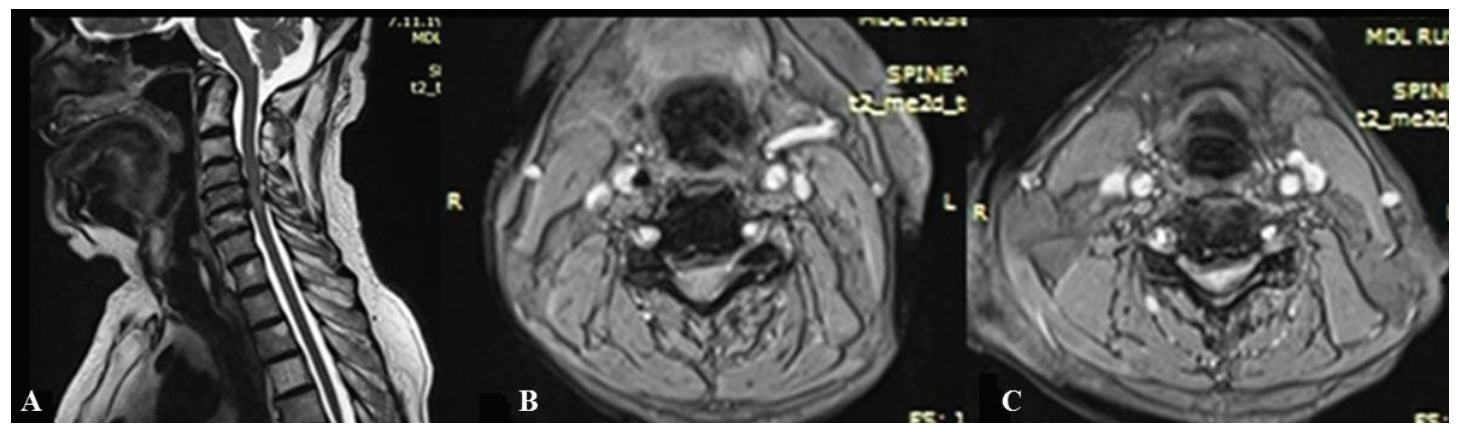

Figure 5. Preoperative MRI (A) Sagittal $\mathrm{T}_{2}$ image of the cervical myelon; $A x i a l \mathrm{~T}_{2}$ images at $\mathrm{C}_{4}-\mathrm{C}_{5}$ level (B) and $\mathrm{C}_{5}-\mathrm{C}_{6}$ level (C). 


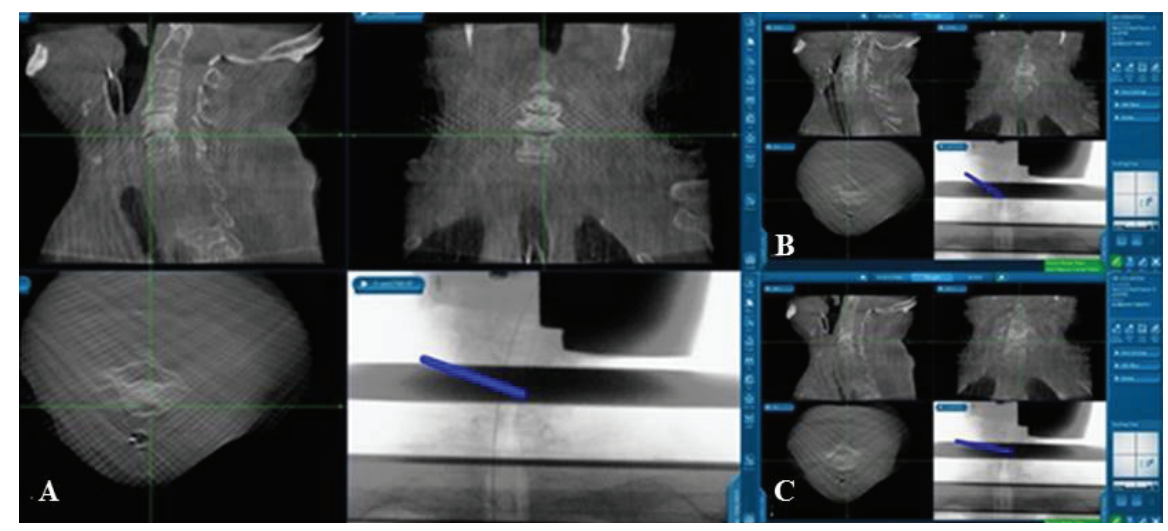

Figure 6. (A) $\mathrm{C}_{5}-\mathrm{C}_{6}$ disc verified with the aid of the cranial navigation probe; (B) Navigated localization of the left and (C) right corpectomy border in strict relation to the midline.

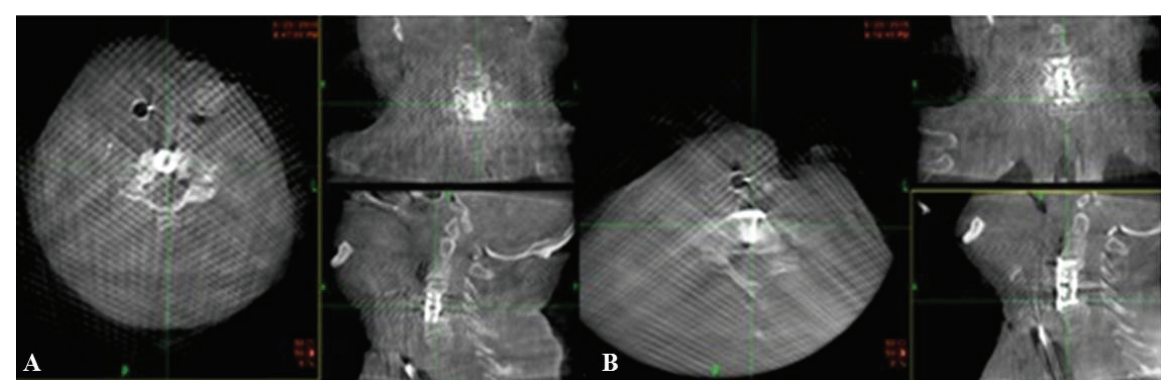

Figure 7. (A) - (B) Final intraoperative 3D scanning to verify optimal implant positioning.

The navigational system allowed easy intraoperative $\mathrm{C}_{4}-\mathrm{C}_{5}$ and $\mathrm{C}_{5}-\mathrm{C}_{6}$ intervertebral discs verification as well as to center the corpectomy strictly in relation to the midline (Fig. 6 A-C). Final intraoperative Oarm scanning verified the scope of decompression as well as optimal positioning of the titanium mesh and plate (Fig. 7 A-B). The postoperative period was uneventful. The clinical examination at 6 months postoperatively showed partial improvement of the motor and sensory deficit (JOA score=12/17).

\section{DISCUSSION}

Our initial experience with the O-arm navigated spinal surgery allowed us to anticipate that this system may significantly increase the precision of spinal instrumented procedures. It allows intraoperative control and immediate correction of misplaced spinal implants that can eventually result in lower incidence of redo surgery. Similar results have been reported by other researchers in the treatment of scoliotic deformities ${ }^{3}$, diseases affecting the cervi$\mathrm{cal}^{4-7}$ and the thoraco-lumbar spine ${ }^{7-9}$. The navigational systems increase the accuracy of pedicle screw placement in spinal segments with difficult anatomy such as upper thoracic spine where lateral projections provided by conventional $\mathrm{C}$-arm are less informative due to overlap of multiple bone structures. ${ }^{10}$ The O-arm navigated surgery can also offer higher precision of pedicle screw placement via minimally-invasive percutaneous procedures. ${ }^{11}$ Mason et al. reported that the percentages of properly placed pedicle screws aided by 3D navigated spinal surgery reached as high as $95.5 \%$, whereas the same percentages achieved by conventional fluoroscopicbased surgery with $\mathrm{C}$-arm was just about $68.1 \%{ }^{12}$

The radiation exposure of the surgical team and the patient substantially decreases in O-arm navigated surgery compared to conventional 2D fluoroscopic-assisted spinal surgery. ${ }^{7,11,13}$

We encountered longer operative time with the use of $\mathrm{O}$-arm spinal navigation in these first two cases. Kotani et al. reported that surgeons could shorten operative time as experience increases. ${ }^{14}$ Similar tendency was noted by Shevelev et al. who reported that a surgeon needs at least 1 month of regular practice with the $\mathrm{O}$-arm navigational system to shorten the operative time. ${ }^{7}$ 


\section{CONCLUSION}

Image-guided O-arm spinal surgery provides high precision and accuracy of instrumented spinal procedures even in cases with altered complex anatomy. Apart from its utilization in different spinal instrumentations, this system can also be used for navigated removal of extradural spinal tumors which can result in more radical resections because in this case "the shift phenomenon" typical of the cranial navigated surgery will not be observed in spinal cases.

\section{REFERENCES}

1. Holly LT, Foley KT. Intraoperative spinal navigation. Spine (Phila Pa 1976) 2003;28(15):54-61.

2. Qureshi S, Lu Y, McAnany S, et al. Three-dimensional intraoperative imaging modalities in orthopaedic surgery: A Narrative Review. J Am Acad Orthop Surg 2014;22(12):800-9.

3. Jin M, Liu Z, Liu X, et al. Does intraoperative navigation improve the accuracy of pedicle screw placement in the apical region of dystrophic scoliosis secondary to neurofibromatosis type I: comparison between $\mathrm{O}$-arm navigation and free-hand technique. Eur Spine J 2016;25(6):1729-37. [Epub ahead of print]

4. Epstein NE. Commentary: Utility of the O-Arm in spinal surgery. Surg Neurol Int 2014;5(15):S517-9.

5. Ishikawa Y, Kanemura T, Yoshida G, et al. Intraoperative, full-rotation, three-dimensional image (O-arm)based navigation system for cervical pedicle screw insertion. J Neurosurg Spine 2011;15(5):472-8.

6. Mattei TA, Rehman AA, Issawi A, et al. Surgical challenges in the management of cervical kyphotic deformity in patients with severe osteoporosis: an illustrative case of a patient with Hajdu-Cheney syndrome. Eur Spine J 2015;24(12):2746-53.

7. Shevelev IN, Konovalov NA, Starchenko VM, et al. [Experience of using an intraoperative cone beam computed tomography scanner and the modern navigation system in surgical treatment of spine and spinal cord disorders]. Zh Vopr Neirokhir Im N N Burdenko 2014;78(3):21-9 (Russian).

8. Rahmathulla G, Nottmeier EW, Pirris SM, et al. Intraoperative image-guided spinal navigation: technical pitfalls and their avoidance. Neurosurg Focus 2014;36(3):E3.

9. Rivkin MA, Yocom SS. Thoracolumbar instrumentation with CT-guided navigation (O-arm) in 270 consecutive patients: accuracy rates and lessons learned. Neurosurg Focus 2014;36(3):E7.

10. Bledsoe JM, Fenton D, Fogelson JL, et al. Accuracy of upper thoracic pedicle screw placement using three-dimensional image guidance. Spine J 2009;9(10):817-21.

11. Kim TT, Drazin D, Shweikeh F, et al. Clinical and radiographic outcomes of minimally invasive percutaneous pedicle screw placement with intraoperative CT (O-arm) image guidance navigation. Neurosurg Focus 2014;36(3):E1.

12. Mason A, Paulsen R, Babuska JM, et al. The accuracy of pedicle screw placement using intraoperative image guidance systems. J Neurosurg Spine 2014;20(2):196-203.

13. Grelat M, Zairi F, Quidet M, et al. Assessment of the surgeon radiation exposure during a minimally invasive TLIF: Comparison between fluoroscopy and O-arm system. Neurochirurgie 2015;61(4):255-9.

14. Kotani T, Akazawa T, Sakuma T, et al. Accuracy of pedicle screw placement in scoliosis surgery: a comparison between conventional computed tomography-based and $\mathrm{O}$-arm-based navigation techniques. Asian Spine J 2014;8(3):331-8. 


\title{
Первоначальный опыт при проведении операции позвоночного столба с помощью навигации с O-Arm - доклад о двух случаях
}

\author{
Иво И. Кехайов ${ }^{1,2}$, Христо Б. Желязков ${ }^{1,2}$, Борислав М. Калнев ${ }^{1,2}$, Атанас Н. Даварски ${ }^{1,2}$, \\ Борислав Д. Китов ${ }^{1,2}$, Стефан Д. Райков ${ }^{2}$ \\ ${ }^{1}$ Кафедра нейрохирургии, Факультет медицины, Медицинский университет, Пловдив, Болгария \\ 2 Клиника нейрохирургии, Университетская больница "Св. Георги", Пловдив, Болгария
}

Адрес для корреспонденции: Иво И. Кехайов, Кафедра нейрохирургии, Факультет медицины, Медицинский университет - Пловдив, бул. Васила Априлова № 15A, Пловдив, 4000, Болгария E-mail:dr.kehayov@gmail.com; dr.kehayov@yahoo.com Тел.: +359899105352

Дата получения: 24 апреля 2016 г.

Дата приемки: 05 июля 2016 г. Дата онлайн публикации: 05 октября 2016 г.

Дата публикации: 23 декабря 2016 г.

Ключевые слова: O-arm, фиксация с помощью педикулярного винта, операция позвоночного столба

Образец цитирования: $\mathrm{Ke}-$ hayov II, Zhelyazkov CB, Kalnev BM, Davarski AN, Kitov BD, Raykov SD. Initial experience with O-Arm navigated spinal surgery - report on two cases.

Folia Medica 2016;58(4):293-298 doi: 10.1515/folmed-2016-0033
Операция позвоночного столба с использованием интраоперационной визуализации обретает все большую популярность, поскольку позволяет хирургам достижение минимальной инвазивности и максимальной точности при проведении процедуры.

Излагаем наш первоначальный опыт в двух случаях проведения операции с использованием O-arm базированной позвоночной навигации в Клинике нейрохирургии при Университетской больнице "Св. Георги“ города Пловдива, Болгария. В первом случае нами было проведено устранение экстрадуральной опухоли позвоночного столба в области шестого позвонка торакального (грудного) отдела позвоночника и фиксация педикулярного винта с помощью навигации с O-Arm. Во втором случае нами была проведена корпектомия пятого позвонка шейного отдела позвоночника и передняя реконструкция позвонка с использованием O-arm навигации, а также слияние с помощью титановой расширяемой сетки и шейной пластины ввиду дегенеративного сужения спинального канала, что явилось причиной клинического проявления миелопатии.

Первоначальный опыт позволяет нам прийти к заключению, что O-arm базированная операция позвоночного столба с использованием интраоперационной визуализации может предложить намного более высокую точность при проведении процедур в области позвоночника. В то же самое время сокращается доза облучения пациента и хирургического коллектива. 